\title{
ECOLOGY AND BIOCONTROL STUDY ON THE WHITE GRUBS, PENTODON BISPINOSUS INFESTING STRAWBERRY ROOTS
}

\author{
Nehal O. Swelam \\ Economic Entomology and Agricultural Zoology Department, Faculty of Agriculture, \\ Menoufia University, Egypt \\ nehal.swelam@agr.menofia.edu.eg
}

Received: Oct., 27, 2021

Accepted: Nov., 7, 2021

\begin{abstract}
An ecological study was conducted to elucidate the peaks of the white grubs' larvae infesting strawberry roots along one year from May 2020 to April 2021. Furthermore, feeding and control study was applied under laboratory conditions. Results revealed that May and September months recorded 20 larvae per root of strawberry plant as the highest numbers of larvae under $17-38^{\circ} \mathrm{C}$ and $32-61 \mathrm{RH} \%$. The larvae of the Pentodon bispinosus were reared on three vegetable roots; however, the grubs have a wide range of host families. The larvae of the P. bispinosus prefer the roots of the Strawberry plants recording the highest weights as $7 \pm 0.6 \mathrm{~g}$ roots/day. Bioinsecticides were tested to determine the most effective agents against white grubs, from the results, the third stage of grubs have resistance against Abamectin $3.6 \%$ and Chitosan. Abamectin 3.6\% EC recorded $30 \%$ reduction in larvae population after 3 days of treatment decreased to $10 \%$ after 30 days, on contrary, Chitosan recorded zero reduction.
\end{abstract}

Key words: White grubs, Biocontrol, rearing diet, Scarabaeidae, hard black beetle

\section{INTRODUCTION}

Strawberry (Fragaria ananassa) is an economic crop in Egypt, and greatly increased over the last ten years, due to longer growing seasons, readily available labor and relatively low cost and vicinity to large national or export markets. The production of strawberry rises from 70,000 million ton in 2000 to 464,000 million ton in 2019, with an increase of fresh export from 338 ton in 2000 to 36,000 million ton in 2019 , and from 15,000 million ton in 2009 to 140,000 million ton as individually quick frozen (UNITC, 2019) (GOEIC, 2020). The Ministry of Agriculture and Land Reclamation in Egypt reported that Egypt ranked first in exporting frozen strawberries all over the world from 2019 till now, the exports of strawberry ranked the eighth between the most important crops to export the governorates of Qaliobia, Beheira, Ismailia, and Sharkia are the most interested in cultivating strawberries.

The white grub, Pentodon bispinosus Kuster, 1852 (Coleoptera: Scarabaeidae) become one of the major pests that reduces the crop of strawberry production. White grub larvae are polyphagous (Abd-Rabou and Saadia, 2006). The larvae of hard back beetle feed on the organic manure wastes in the soil especially sand soil near the surface and under the vegetable roots and its feeding causes fast dry to the plant causing great losses. White grubs are difficult to control duo to its habits of living and the hardness of its body (Devi, 2019). Polyethylene mulched growing system displayed the plants to the root feeding weevils (Cross et al., 2001).

Systemic pesticides used against white grubs have direct and indirect objectionable effects on other organisms 
in the ecosystem (Choudhury et al., 2020) against the beneficial predators as coccinellid beetles, predatory mites, and hymenopteran parasitoids, in addition to the increase of the environmental pollution (Abd El-Salam et al., 2013; Parra, 2014; Lee et al., 2017; Tappert et al., 2017; Skouras et al., 2019).

The application of insecticides against white grubs has two strategies (preventative and curative). The first strategy requires insecticides with late residual activity in the soil before a potential problem (2-3 months before hatching), and these insecticides should not be harmful to any ecosystem organisms or the environment. The curative process starts after egg hatching, and the larvae have made a little damage in mid-August. The preventative strategy is more effective than the curative (Potter and Potter, 1999).

Rani et al., 2021 reared grubs to study the biology of white grubs, the neonates (at the first day of hatching) moved individually on live roots of (7-10 days maize in sandy soil in pots) moisture adequate weekly to avoid food, environmental stress, and cannibalism, The newly hatched grubs feed on

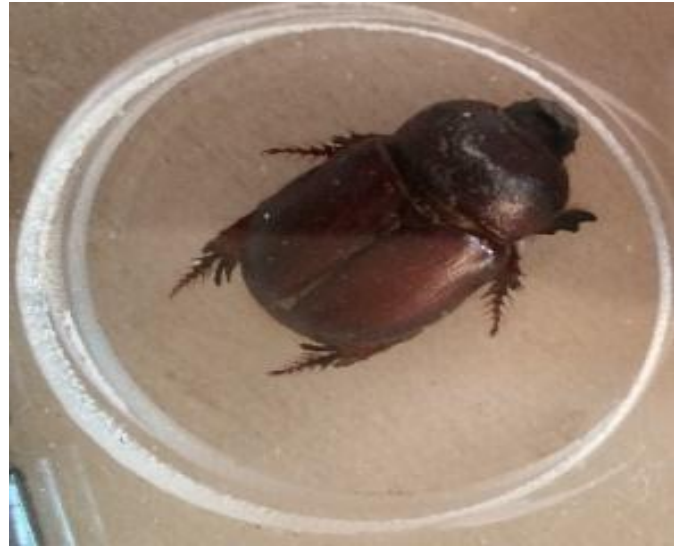

(a) decaying organic matter and then on the host plant roots.

Recently, Abd El-Salam, 2019 showed that Imidacloprid had the highest lethal impact against white grubs followed by Bio-catch, while Nimbecidine showed the lowest impact after twice applications.

From the previous review, this study was conducted to study the ecology of Pentodon bispinosus under field conditions, as well as to study the food preference of the beetle under laboratory conditions, and to evaluate the efficacy of some bio insecticides against the white grub, Pentodon bispinosus,

\section{MATERIALS AND METHODS}

\section{Tested insect:}

The larvae of the white grub, Pentodon bispinosus (Fig. 1) were collected from different farms located in Badr center, EI Beheira Governorate, Egypt, and reared under laboratory conditions which served as a source to conduct feeding and toxicological studies. Collected larvae were reared in glass boxes $30 \times 30 \times 25 \mathrm{~cm}$ filled with sand and support with food and water as needed.

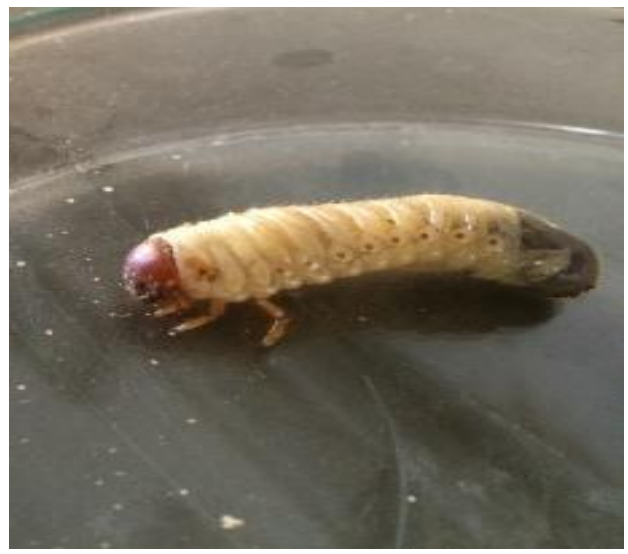

(b)

Fig. (1): (a) the adult (b) larva of the hard back beetle, Pentodon bispinosus 


\section{Field experiment:}

An ecological study was conducted during the 2020/2021 months to determine the peaks of the population of the white grubs on strawberry. Samples were weekly collected along the period from May 2020 to April 2021 by digging under the strawberry plants and the percentage of the infested plants and the numbers of larvae under every root plant were recorded as numbers per root.

\section{Laboratory experiments:}

Food ability experiment:

The 3rd instar larvae of the white grub, P. bispinosus were reared, during March month to study the food preference of arugula, carrot, strawberry, where one larva was provided with food, replicated three times for each kind of food, observed till pupal stage. Food and water was added as needed and the weight of each was determined.

The grubs were observed by digging in the sand, collected, and identified in the laboratory by the identification key of Scarabaeidae larvae (López-García, 2015). Larvae were separated each one put in a $250 \mathrm{ml}$ glass jar filled with sandy soil. Larvae were provided daily with tested plant roots till the larvae reach the pupal stage. The consumed root weight was calculated by subtracts the weight after feeding from the preweighted plant roots.

\section{Control study:}

To study the effect of Chitosan and Abamectin against $3^{\text {rd }}$ instar larvae of the white grub, Pentodon bispinosus, five larvae were potted in $250 \mathrm{ml}$ glass jar filled with sand soil treated with the recommended dose of each material. Treatments were replicated five times, and the jars were examined daily to determine the reduction percentage of each treatment.

\section{Tested insecticides:}

\section{Chitosan:}

Chitosan is a versatile biopolymer that Is Nontoxic, is a sugar obtained from the hard outer skeleton of shellfish, including crab, lobster, and shrimp, and was applied at the rate of 3 liter/ feddan.

\section{Abamectin:}

Abamectin $(3.6 \% \mathrm{EC})$ is an insecticide used widely, is one from the family of Avermectin and is one of the avermitilis family (natural product of soil dwelling (actinomycete Streptomyces), was applied at the rate of 3 liter/ feddan.

\section{Temperature and relative humidity:}

Temperature and relative humidity were noted daily during the study and weekly averages were calculated (Table 1).

\section{Statistical analysis:}

Data were subjected to the analysis of variance test (ANOVA) as randomized complete blocks design. The least significant differences (LSD) at the 5\% level were determined using a computer program (CoStat, 2008) and Duncan's Multiple Range testes and LSD 5\% values were used to compare the average mean numbers. Reduction percentages were counted according to Abbott's formula.

Increase or decrease \% = Control - treatment / Control x 1009 
Table (1): Average numbers of air temperature and the relative humidity along year months

\begin{tabular}{|c|c|c|c|c|c|c|c|}
\hline Month & $\mathrm{C}^{\circ}$ & $\mathrm{C}^{\circ}$ & $\mathbf{R H} \%$ & Month & $\mathrm{C}^{\circ}$ & $\mathrm{C}^{\circ}$ & $\mathbf{R H} \%$ \\
\hline \multirow{4}{*}{ May 2020} & 36 & 17 & 46 & \multirow{4}{*}{ Nov. 2020} & 26 & 17 & 58 \\
\hline & 37 & 17 & 44 & & 26 & 16 & 59 \\
\hline & 43 & 20 & 32 & & 24 & 13 & 63 \\
\hline & 31 & 17 & 48 & & 24 & 14 & 69 \\
\hline \multirow{4}{*}{ Jun. 2020} & 37 & 17 & 45 & \multirow{5}{*}{ Dec. 2020} & 23 & 13 & 49 \\
\hline & 39 & 20 & 37 & & 27 & 11 & 44 \\
\hline & 42 & 21 & 45 & & 27 & 12 & 58 \\
\hline & 40 & 22 & 48 & & 22 & 10 & 75 \\
\hline \multirow{5}{*}{ Jul. 2020} & 36 & 22 & 51 & & 22 & 10 & 78 \\
\hline & 37 & 24 & 51 & \multirow{5}{*}{ Jan. 2021} & 19 & 08 & 52 \\
\hline & 36 & 23 & 57 & & 18 & 08 & 59 \\
\hline & 36 & 23 & 60 & & 21 & 10 & 63 \\
\hline & 37 & 23 & 58 & & 17 & 06 & 56 \\
\hline \multirow{4}{*}{ Aug. 2020} & 38 & 24 & 52 & & 19 & 06 & 57 \\
\hline & 36 & 19 & 57 & \multirow{4}{*}{ Feb. 2021} & 22 & 09 & 54 \\
\hline & 37 & 24 & 58 & & 24 & 09 & 60 \\
\hline & 36 & 24 & 56 & & 20 & 10 & 66 \\
\hline \multirow{5}{*}{ Sept. 2020} & 38 & 25 & 61 & & 26 & 09 & 51 \\
\hline & 37 & 25 & 61 & \multirow{4}{*}{ Mar. 2021} & 26 & 11 & 50 \\
\hline & 37 & 23 & 60 & & 30 & 12 & 72 \\
\hline & 35 & 23 & 58 & & 26 & 10 & 59 \\
\hline & 38 & 22 & 55 & & 28 & 10 & 48 \\
\hline \multirow{4}{*}{ Oct. 2020} & 37 & 21 & 60 & \multirow{5}{*}{ Apr. 2021} & 34 & 13 & 35 \\
\hline & 32 & 19 & 58 & & 31 & 14 & 53 \\
\hline & 33 & 20 & 61 & & 28 & 14 & 55 \\
\hline & 29 & 20 & 64 & & 34 & 15 & 48 \\
\hline & & & & & 32 & 16 & 46 \\
\hline
\end{tabular}

\section{RESULTS AND DISCUSSION}

1-Seasonal fluctuations of the white grub of $P$. bispinosus infesting strawberry roots along 2020- 2021 months at EI Beheira Governorate:

The obtained results in Table (2) indicated that the larvae prefer the mild climate $\left(17-38^{\circ} \mathrm{C}\right.$ and $32-61 \mathrm{RH} \%$ ) where the larvae has the most dispertion in May and September followed by April and October.
2-Rearing white grubs, Pentodon bispinosus:

The obtained results in Table (3) showed that the grubs have a wide range of host families (Brassicaceae, Apiaceae, and Rosaceae) as it successfully reared on arugula, carrot, and strawberry, respectively, but it greatly prefers the roots of the strawberry plants among the tested plants. 
3-The effect of Chitosan and Abamectin against white grubs, $P$. bispinosus:

The data of Table (4) showed that the third stage of the larvae of white grubs, Pentodon bispinosus have resistance against Chitosan and Abamectin 3.6\% EC with the recommended dose, although the Abamectin recorded $30 \%$ reduction in the population of the pest but this is not enough to reduce the damage happened.

Table (2): Average numbers of the white grub, Pentodon bispinosus larvae /strawberry plant along year months

\begin{tabular}{|l|c|c|c|c|c|c|c|c|c|c|c|c|}
\hline \multirow{2}{*}{ month } & \multicolumn{7}{|c|}{2020} & \multicolumn{5}{c|}{2021} \\
\cline { 2 - 14 } & May & Jun. & Jul. & Aug. & Sept. & Oct. & Nov. & Dec. & Jan. & Feb. & Mar. & Apr. \\
\cline { 2 - 13 } & \multicolumn{8}{|c|}{ average numbers of larvae /10 plant root } \\
\hline Rep. 1 & 20 & 10 & 5 & 6 & 20 & 15 & 10 & 2 & 0 & 0 & 3 & 15 \\
\hline Rep. 2 & 18 & 10 & 4 & 5 & 17 & 12 & 12 & 2 & 0 & 0 & 3 & 17 \\
\hline Rep. 3 & 22 & 10 & 6 & 4 & 23 & 18 & 8 & 2 & 0 & 0 & 3 & 13 \\
\hline Mean & $20 \mathrm{a}$ & $10 \mathrm{c}$ & $5 \mathrm{~d}$ & $5 \mathrm{~d}$ & $20 \mathrm{a}$ & $15 \mathrm{~b}$ & $10 \mathrm{c}$ & 2 ef & $0 \mathrm{f}$ & $0 \mathrm{f}$ & $3 \mathrm{de}$ & $15 \mathrm{~b}$ \\
\hline LSD5\% & \multicolumn{10}{|c|}{2.75} \\
\hline
\end{tabular}

mean values followed by the same letter(s) are not significantly different by $(P=0.05)$ according to Duncan's multiple range test.

Table (3): The ability of Pentodon bispinosus to eat

\begin{tabular}{|l|c|}
\hline Plant roots & grams/ day / larva \\
\hline Arugula, Eruca sativa & $2 \pm 0.13$ \\
\hline Carrot, Daucus carota & $5 \pm 0.32$ \\
\hline Strawberry, Fragaria $x$ ananassa & $7 \pm 0.60$ \\
\hline
\end{tabular}

Table (4): Reduction \% of the white grub, Pentodon bispinosus

\begin{tabular}{|l|c|c|c|}
\hline \multirow{2}{*}{ Days after application } & \multicolumn{3}{|c|}{ Reduction \% } \\
\cline { 2 - 4 } & Chitosan & Abamectin3.6\% EC & Control \\
\hline 1 day & 0 & 0 & 0 \\
\hline 3 days & 0 & 30 & 0 \\
\hline 7 days & 0 & 0 & 0 \\
\hline 10 days & 0 & 0 & 0 \\
\hline 20 days & 0 & 0 & 0 \\
\hline 30 days & 0 & 10 & 0 \\
\hline Total & 0 & 40 & 0 \\
\hline
\end{tabular}




\section{REFERENCES}

Abd El-Salam, A.M.E. (2019). Field Evaluation of Some Eco-Friendly Formulations against Strawberry White grubs in Egypt. Specialty Journal of Biological Sciences, 5 (2): 1-6.

Abd El-Salam, A.M.E., H.A. Salem and S.A. Salem (2013). Biocontrol agents against the leafminer, Liriomyza trifolii in Faba bean fields. Archives of Phytopathology and Plant Protection, 46(9):1054-1060.

Abd-Rabou, S. and Saadia A. Abd-ElSamea (2006). New records of scarabaid white grub species and diptrean genus in sugar cane soil in upper Egypt (Coleoptera: Scarabaeidae). Egypt. Journal of Agriculture Research, 84 (3):797-801.

Abbott, W.S. (1925). A method for computing the effectiveness of an insecticide. J. Econ. Entomol. 18: 265 $-267$.

Choudhury, R A., A.M. Sutherland, M.J. Hengel, M.P. Parrella and W.D. Gubler (2020). Imidacloprid movement into fungal conidia is lethal to mycophagous beetles. Insects 11: 496-502. doi:10.3390/insects11080496.

CoStat version 6.400 copyright (C) 19982008: Cohort Software. 798 Lighthouse Ave. PMB 320, Monterey, CA, 93940, USA.

Cross, J.V., M.A. Easterbrook, A.M. Crook, D. Crook, J.D. Fitzgerald, P.J. Innocenzi, C.N. Jay and M.G. Solomon (2001). Review: Natural enemies and biocontrol of pests of strawberry in Northern and Central Europe. Biocontrol Science and Technology, 11: 165-216.

Devi, G. (2019). White grub management by entomopathogenic nematodes. International Journal of Current Research, 11(12): 8876-8886.

GOEIC (2020). Ministry of Trade and Industry, General Organization for
Export and Import Control, Egypt. https://www.exports-to-

egypt.com/en/about. Accessed 30 August 2020.

Lee, Y.S., M.J. Jang, H.A. Lee and J.H. Lee (2017). Toxicity of pesticides to mycophagous ladybird, IIleis koebelei Timberlake (Coleoptera: Coccinellidae: Halyziini). Korean J. Pestic. Sci. 21: 364-372.

López-García, M.M., H.J. Gasca-Álvarez, and G. Amat-García (2015). The scarab beetle tribe Pentodontini (Coleoptera: Scarabaeidae: Dynastinae) of Colombia: taxonomy, natural history, and distribution. Zootaxa 4048(4), 451492.

Parra, J.R.P. (2014). Biological control in Brazil: an overview. Sci. Agric. 71: 420-429.

Potter, D.A. and M.F. Potter (1999). Controlling White Grubs in Turfgrass. Educational programs of the Kentucky Cooperative Extension, University of Kentucky College of Agriculture, Lexington, and Kentucky State University.

Rani, S., Riazuddin, R. Saharwat, M. K. Sharma and J. Singh (2021). Biology study of white grub Holotrichia nagpurensis (Scarabaeidae: Melolonthinae). International Journal of Agricultural and Applied Sciences. 2(1): 57-60. https://doi.org/10.52804/ijaas2021.216.

Skouras, P.J., M. Brokaki, G.J. Stathas, V. Demopoulos, G. Louloudakis and J.T. Margaritopoulos (2019). Lethal and sub-lethal effects of imidacloprid on the aphido-phagous coccinellid hippodamia variegata. Chemosphere 229: 392-400.

Tappert, L., T. Pokorny, J. Hofferberth and J. Ruther (2017). Sub lethal doses of Imidacloprid disrupt sexual communication and host finding in a parasitoid wasp. Sci. Rep. 7: 42756. 


\title{
دراسة ايكولوجية ومكافحة حيوية على يرقات الجعل ذو الظهر الجامد التى تصيب جذور الفراولة
}

\author{
نهال أمية محمد سويلم
}

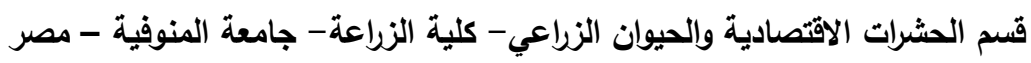

الملخص العربي

أجريت دراسة بيئية على حشرة الجعل ذو الظهر الجامد لتحديد أوقات نشاط الحشرة خلال العام وخاصة خلال موسم

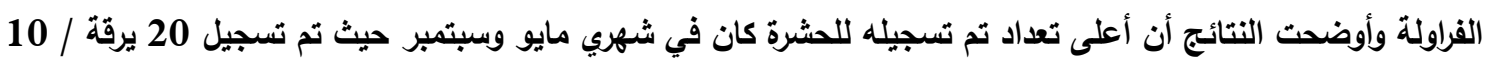

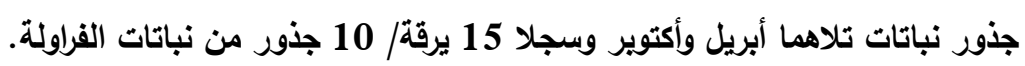
تم عمل تجربة معملية لقياس فاعلية مبيدي الثيتوزان والأبامكتين بتركيز 3 لتر للفدان مستخدمة لمكافحة يرقات

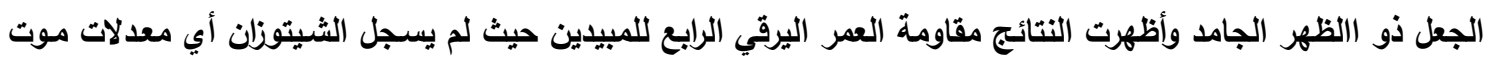

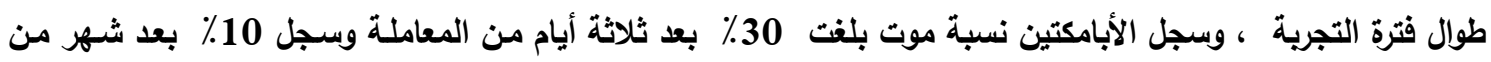

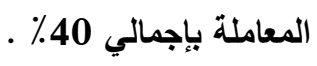

كذلك أجريت دراسة على قابلية اليرقات للتغذية على بعض جذور نباتات العائلة الصليبية والعائلة الخيمية والعائلة

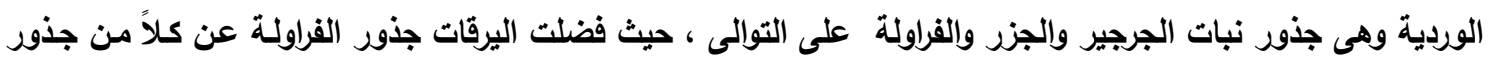

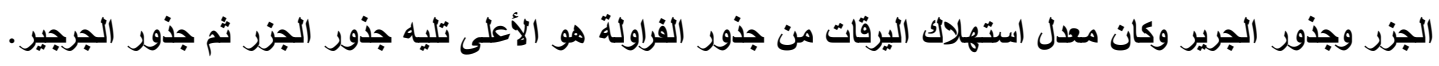

